\title{
Building transformation in Bandung city centre: Expansion of land lot at Pasar Baru area
}

\author{
Soewarno Nurtati ${ }^{1}$, Hidjaz Taufan ${ }^{2}$, Virdianti Eka ${ }^{1}$ \\ ${ }^{1}$ Architecture Department. Institut Teknologi Nasional, Bandung-Indonesia \\ ${ }^{2}$ Interior Design Department, Institut Teknologi Nasional, Bandung-Indonesia \\ E-mail: nts_80@yahoo.com,htaufanhidjaz@yahoo.co.id,virdianti_eka@yahoo.co.id
}

\begin{abstract}
City as a man creation is always experiencing transformation from time to time. The city center area, originating from a residence area has turned into a commercial area for trading. This transformation is recognized by the physical building change. This paper will describe building transformation in the Pasar Baru area, which is a conservation area in the city center of Bandung city, Indonesia. Colonialism left dualism of the land status in this area, formal and informal. Formal land is located on the road side shaped as row shop houses whilst the informal land lies behind the shop houses in form of urban kampong. The improvement of business and trading, demands a larger working area so space expansion is needed. The difference of land status and location makes it possible for shop house owners to expand their lot toward the kampong behind. Nowadays old shop houses as conservation buildings are hard to recognize because they have been transformed into new shop house forms. By observing the shape it's expected that the lot expansion was the motivating factor. How did the transformation occur? Can transformation on one land lot give contribution to transformation on the city? It's expected that the occurring transformation should not eliminate the conservation, building and area in the city center and the residential function could still be maintained
\end{abstract}

Keywords: Territorial expansion, building transformation, conservation area

\section{Introduction}

Almost all major cities in Indonesia were estabilished during the Dutch-colonial era. The Colonial government constructed city centers not far from the existing village or kampong. The increasing of the urban economics cause the villages develop into trading areas with the village market as center. In Bandung city the area mentioned above is Pasar Baru trading area with the market as a center point. At the beginning this area was known by the row shop houses built with various architectural styles i.e. Traditional Sundanese, Chinesee and Indishe (mixed between European and Indonesian style).
At present, the Pasar Baru area become a trade center serving not only Bandung city but also cities surrounding Bandung. The high demand for trade activity space cause there is little habitable space left, thus the shop houses are used only for trading activity during day time and left empty during night time. Function alteration also could be seen on some shop houses that transforms into offices, restaurants and mini markets, which are also unoccupied during night time.

Besides function alteration also occur on building physic. The shop house tends to transform into irregular shapes such as 
flat slim building extend backward, broken shapes or become a larger building then the other building surrounding it. This kind of transformation is identified as an impact of the land lot dimension transformation that enlarge or shrink corresponding to owners that buy or sell their land followed by construction of new building according to new land lot shape.

This paper is going to review the building transformation types caused by land lot dimension and shape change, causative factor and the impact to buildings and the surrounding environment. Will the transformation occurring to these buildings create a new form of the Pasar Baru trade area? Interference from the Local Government is expected to resolve the transformation process considering this area have been set as a cultural heritage in Bandung city. The high number of transformation case is feared to eliminate the remaining cultural heritage building in this area. One way to handle the problem is to directing the transformation by revitalization of the building as one way to preserve the cultural heritage.

\section{Methodology}

To review the land lot alteration, accurate field data is required, so grounded research is estimated fit for this paper. A few case studies are chosen and grouped based on land lot dimension change; divided and fused. Besides of that, search of old data from literature such as history books, pictures and earlier research. Some interviews are held to competent sources IE building owners, Local Government and local community to complete needed data. This research is considered qualitative research because there is no mathematics calculation in each case study.

\section{Measurement and Analysis}

\section{I.Literature Review}

\section{I.1 Territorial Expansion;}

In this paper the term of territorial expansion is the expansion of area caused by the expansion of land lots. The expansion of land lots tend to be followed by changes in elements located on it, which is building. This could lead the transformation, as Habraken (1983) state: site can be transformed by the addition, removal or change the position of elements.

\section{I.2 Building Transformation}

According to Antoniandes (1990) transformation is a slowly changing process until it reaches its peak. Changes are responses to external and internal influences that direct the changing from known shapes before, through repeatedly reduplicating or doubling the object. Alexander (1987) describes transformation as a slow and unpredictable process with the beginning and end shifting, depending on the influencing factors. The nature is comprehensive and sustainable and has connections with social values in the society. In the presence of various forces, architecture of physical forms, mainly buildings, transform through changes to their shapes. Those changes carry with them significant influences to shaped spaces, through either inner space formations, outer formation or space formations in between.

\section{I.3 Conservation Area}

In Bandung city there are 7 area that have been established as conservation area. These area considered worthy of preservation because of its special architectural and historic interest, one of them is China town. China town locate in the city centre of Bandung close to Pasar Baru market; so that many of shop houses at Pasar Baru area have Chinese architectural style.

In the city center there is China town which also conservation area. The location of China town close to Pasar Baru market According to the term conservation area nearly always applies to an area (usually urban or the core of a village) considered worthy of preservation or enhancement because of its special architectural or historic interest. 


\section{Pasar Baru area as a case study II.1 Location}

The Pasar Baru area is the oldest commercial area which located at Otto Iskandardinata Street in the city center of Bandung. Otto Iskandardinata Street is a second class street in Bandung. This street cut perpendicular the first street, Asia Afrika and connect the Resident's house (the head of Bandung and the surroundings) in the North with the Tegallega horse racetrack in the South part of Bandung (Figure 1).

\section{II.2 Historical back ground}

The Pasar Baru area originated from a kampong. The colonial government implemented grid pattern for this area that was planned to be the city center. So that plantation farms become divided into blocks with various extents and every block was surrounded by 4 streets. Every block consists of outer block, along the streets and inner block inside.

Rapid development of the city encourage change. Slowly but surely the outer part of the block becomes more and more dense by buildings well ordered facing the main street. These buildings follows regulation issued by the Colonial government, as for the ownership of the land lot. Different case happens in the inner block, land is controlled and managed by the indegenous people as customary land and buildings were built without permit and with no rules to follow (Figure 2).
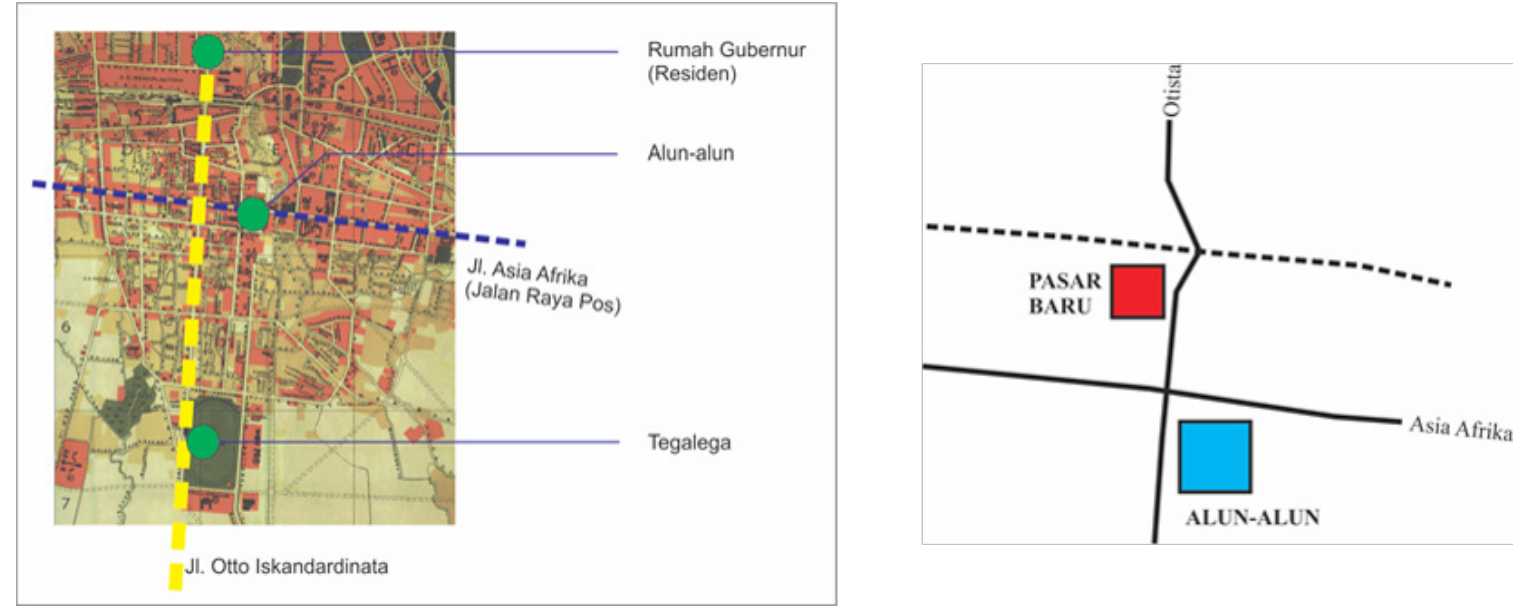

Figure 1. (The location of Pasar Baru area (Processed from Source Voskuil, 1996)
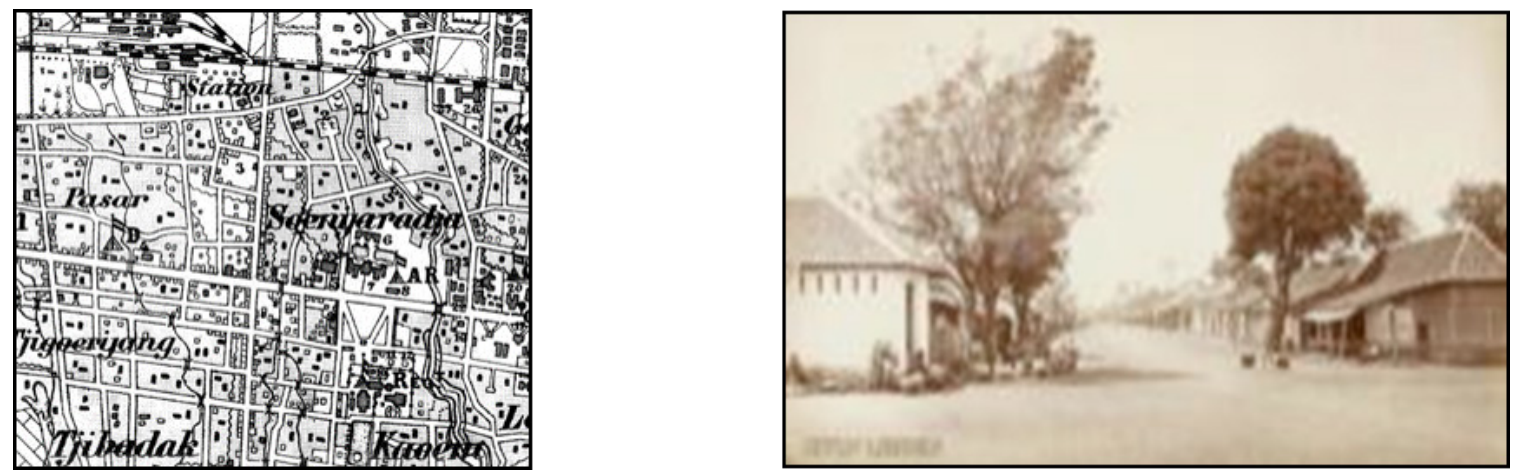

Figure 2. (Grid Pattern at the City Centre and some houses at Otto Iskandardinata Street in year 1882 (Source KITLV-Leiden) 
This condition is the cause of the difference of type, material and building style between outer block and inner block buildings as well for the inhabitants. The inner block, settled by indegenous Sundanese scociety whilst the outer block setteled by the mixture of indegenous and newcommer. This difference $a$ lso $b$ rings forth different architectural shape. There are two block types that differes by the access achievment (Siregar, 1990) which are; close type and open type (Figure 3). The entryway into the block is in the form of alley between rows of buildings of the outer block.

The succses of tea and quinine plantation arround Bandung increases the economic matters to the city and brings impact to the city development. In the year 1906 Bandung was assinged as a municipality (gementee), so the city government have the right to built its own city, then some Building Regulations were issued, one of them were that buildings along the main streets (outer block) should be permanent buildings (Kunto, 1984). This encourages transformation to main street buildings included Otto Iskandardinata street (before; Pasar Baroe weg).

Transformation foremostly is seen in the Pasar Baru trade area, buildings transforms into shop houses, beginning by adding impermanent shop function in the front part. This form is the pioneer of the shop houses along the trade area of Otto Iskandardinata street or Pasar Baru area (Figure 4).

Transformation is also followed by change of land ownership. The skill and precistence of the Chinese people in the trading field, slowly but surely replace the indigenous traders. This is seen by the domination of Chinese shop house in the Pasar Baru area, followed by other buildings along the Otto Iskandardinata street (Figure 4).

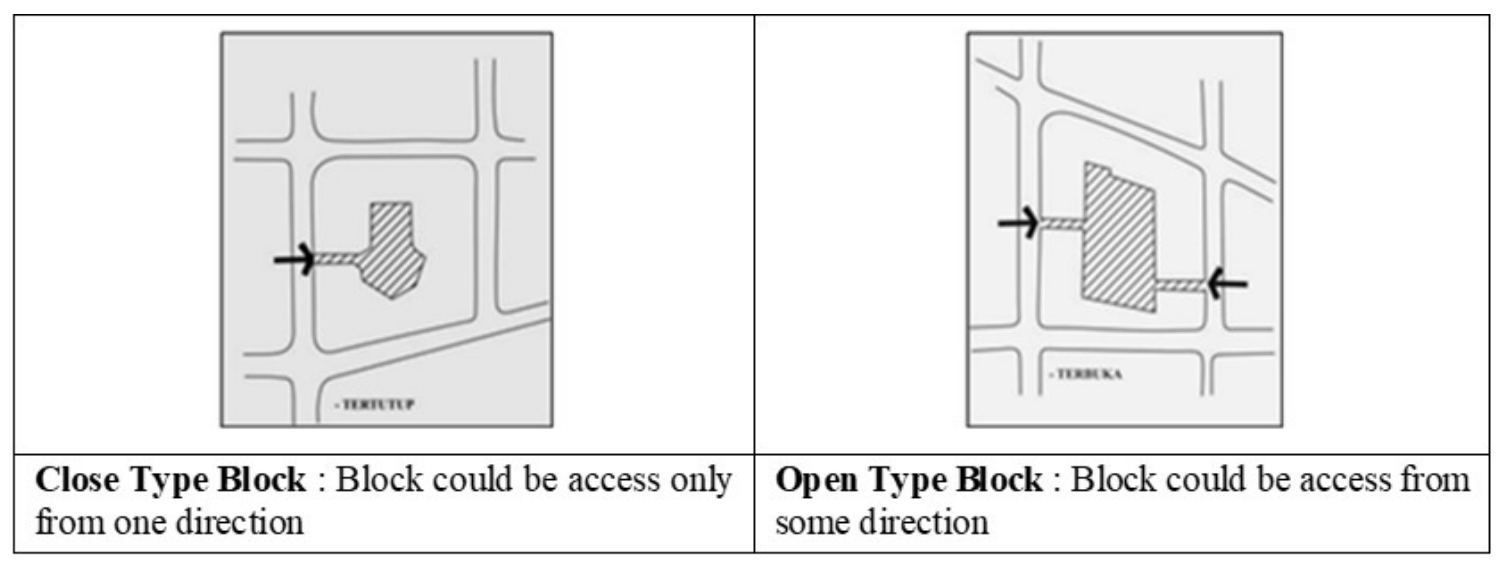

Figure 3. (Type of Block (Processed from Source Siregar, 1990))

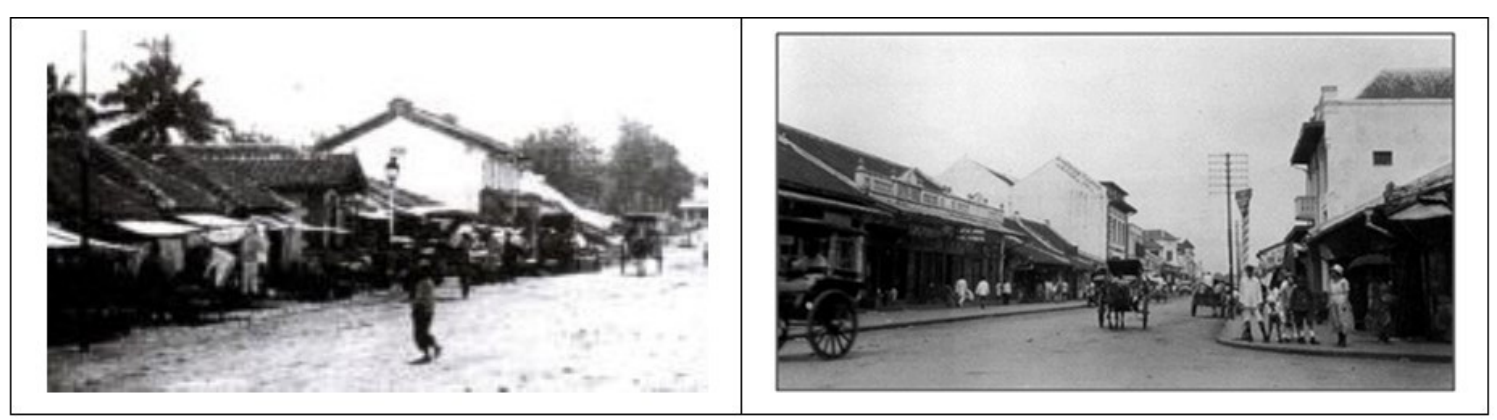

Figure 4. (Simple shop-house and some Chinese shop houses at Otto Iskandardinata Street in year 1990's (Source Voskuil, 1996)) 


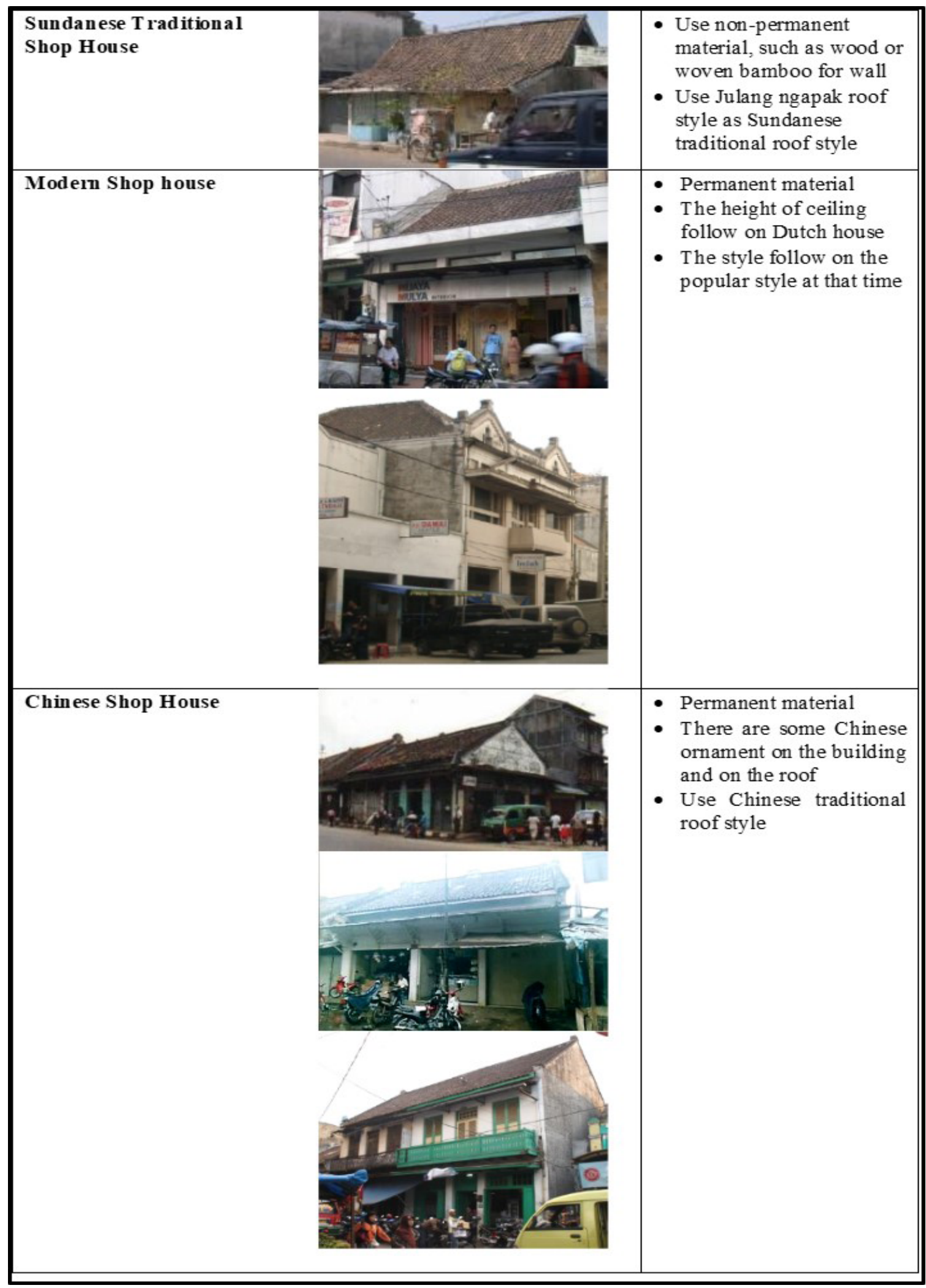

Figure 5. (Typology of shop houses at Otto Iskandardinata Area (Source Personal Document) 


\section{II.3 Typology of shop house}

Observation on site nowadays could still find the remains of old buildings. Some are not intact anymore, some others have changed. From some of the remaining left, the original shape could be recognised. Various factors have changed, one of them is road widening that causes the building's facade changed, the beauty of architectural style disappeared. The other factor is the implementation of arcade system on the pedestrian sidewalk, its causes the front part of the house used as pedestrian, reducing the building area.

From the various architectural styles found, some shop house types along Otto Iskandardinata street (Figure 5).

\section{II.4 Present Condition}

\section{II.5 The Transformation}

As presented before, buildings in this area have experienced changes several times. Beginning with building material change, function change and building physical change with several causative factors. Those changes occurs only to buildings located alongside the street or outer block.

The inner block in general dont experience significant change. From observation on site nowadays, transformation in the inner block have also accured. Buildings in the inner block transforms following buildings in the outer block so there is no difference between buildings in the inner and the outer block. Observation to a few cases found two types of transformation, see in table of analysis 2 and 3.

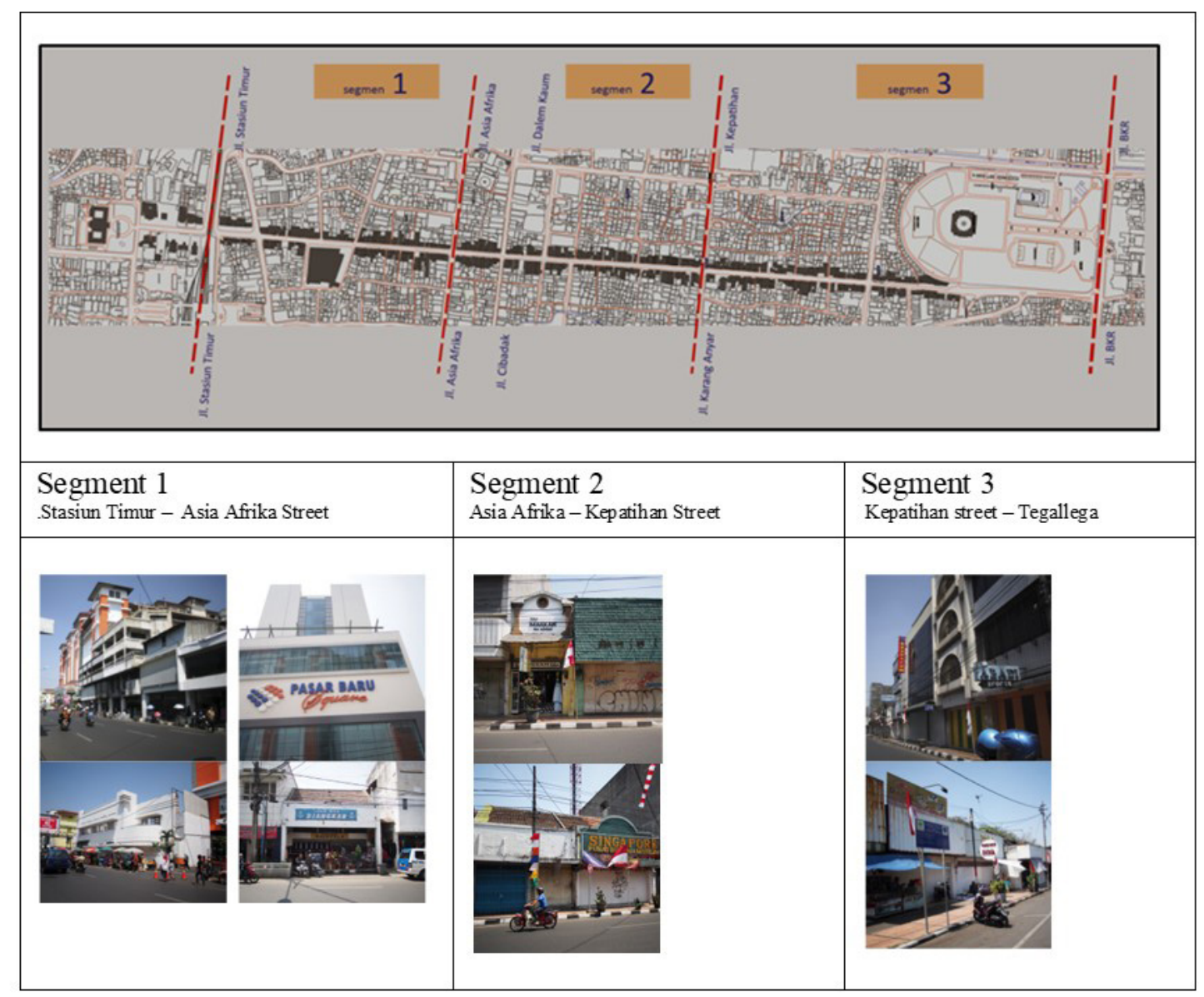

Table 1. Present condition of buildings in Pasar Baru area 
a) Type 1: Fragmentation. There are 3 cases in this type, see in table of analysis 2.
Analysis of type 1:

- Land lot and shop house building divided

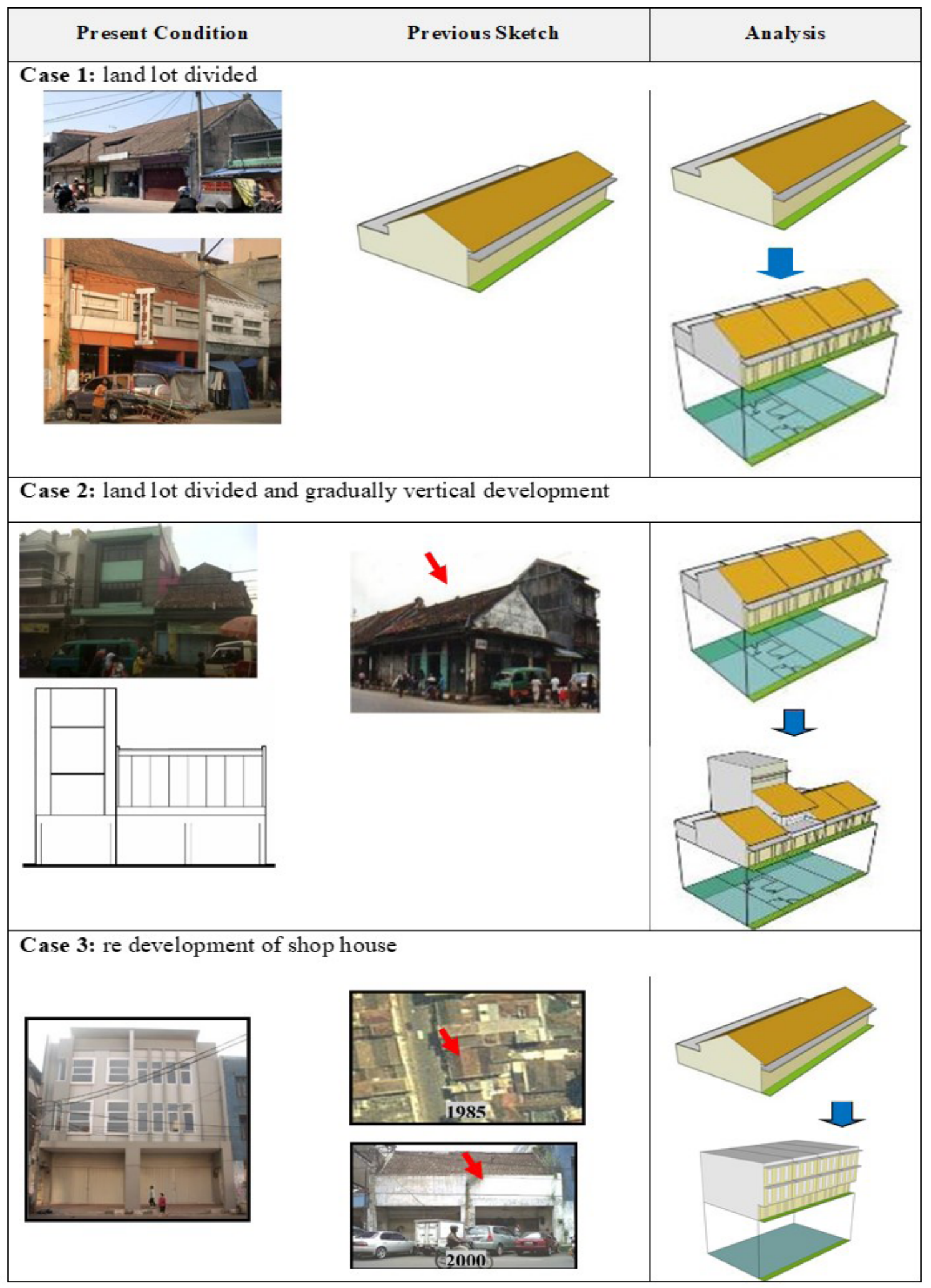


into several unit, depends on the length of the building.

- Division is occuring crosswise so each unit still have access to the main road.

- In case 1, shop house building do not experience changes. The differences of ownership could be indentified from the differences colour, façade, door and window frame design.

- In case 2, the building is not intact any more, already divided. The differences of ownership could be identified by the development. Some units become vertical shop houses and some leave old face. The initial shape of the building could still be recognized from the remaining roof ornament that at the beginning was located in the middle of the roof and also from the building remains.

- In case 3, the old shop house was destroyed first then built vertically into several units depending on length of the building. This case create new form and style of shop house

These three cases have similarities, building and land lot had divided without expansion land lot. In case 2 and 3 the addition of space occurs vertically by adding floor.

b)Type 2: Amalgamation. There are 2 cases in this type, see in table of analysis 3.

\section{Analysis of type 2:}

The building transformation that occurs parallel with the expansion and merger of land lot.

- In case 1 , division done, the ownership bought new land lot and merged it. The construction occurs gradually along with the land lot purchase prosess.

- In case 2, merge some land lot and simultaneously development by individual.

- Case 1 and 2 produce irregular buildings, identical to the land lot shape.

- In case 3: Division is done simultaneously or at once after the land purchase prosess is finished. This type of transformation produce new shop house building type which consist several unit to sell or to rent. This type of commercial building most common in the commercial area in some big cities in Indonesia.
These 3 cases have similarities, the expansion of land lot occurs toward the rear (left and or right), to inner block. Inner block is kampong area or urban kampong which land lots belong to the community as customary land. The land have no certificate and called informal land.

At present urban kampong considered potential, so many parties desire to have that location. This can be seen from many cases of land expansion that occured towards to urban kampong, both by individuals (case 2) or developers (case 3 ) despite the status of informal land.

\section{Analysis:}

- The building transformation occurs gradually starting from fragmentation. In many cases fragmentation will follow by vertical development.

- High demand for trading activities encourages amalgamation. Cases of amalgamation generally occur toward the back, to inner block.

- Individual cases of amalgamation will occur gradually over long periods of time and will create irregular form of shop house, identical to the land lot shape.

- Cases of amalgamation by developer will occur simultaneously in the fast period and create regular form of shop house with gigantic size.

- Advance of trading demands more space and since space is limited, generally the residential function is pushed out, the shop house is only used for trading.

- Understanding shop house as one residential and trading building that have experienced changes.

- The possibility of shop house still inhabited is on case 2 type 2 where residential located at the back part, at inner block.

- Both transformation types, fragmentation and amalgamation results one conclusion that the ownership of shop houses have encounter changes. 


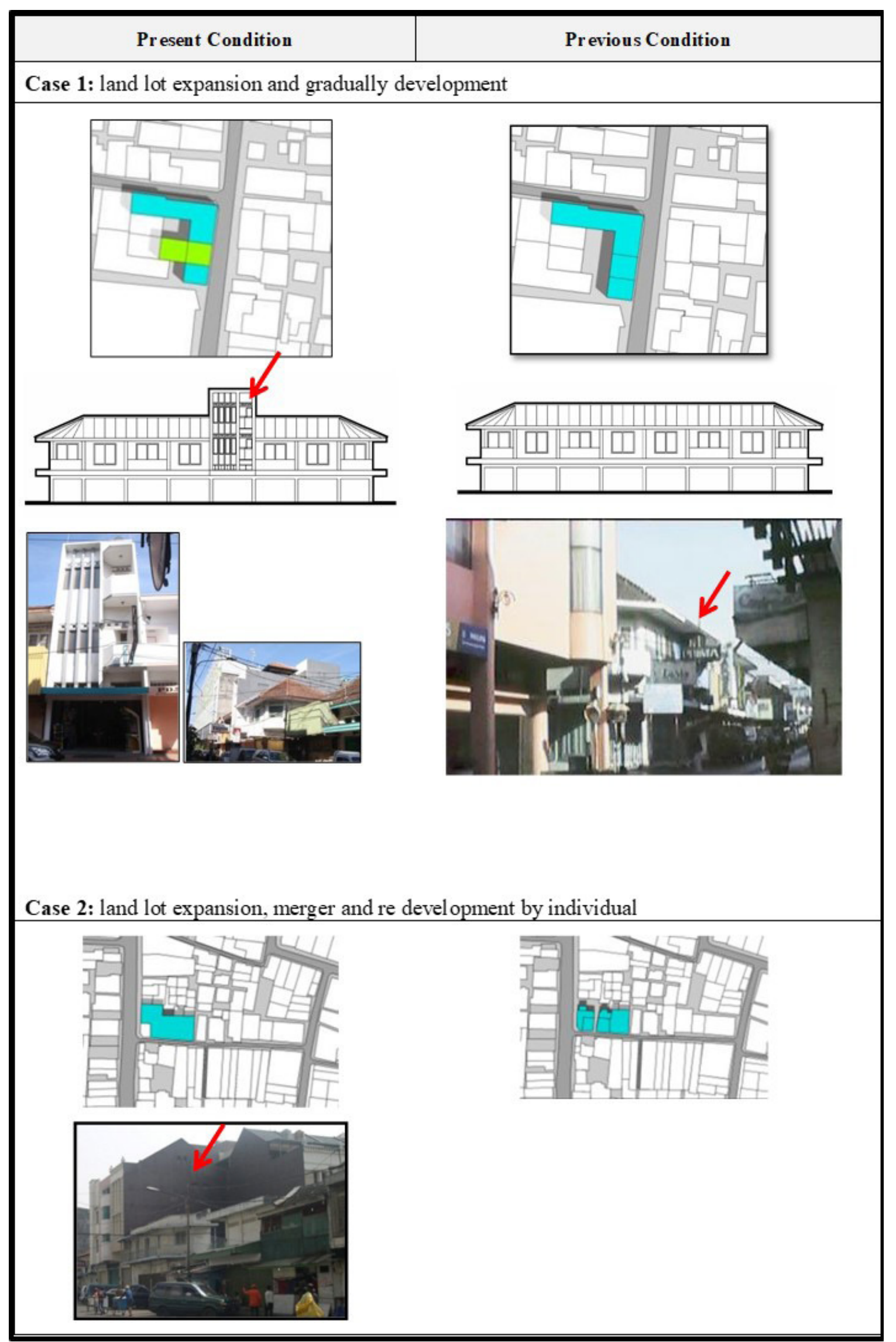



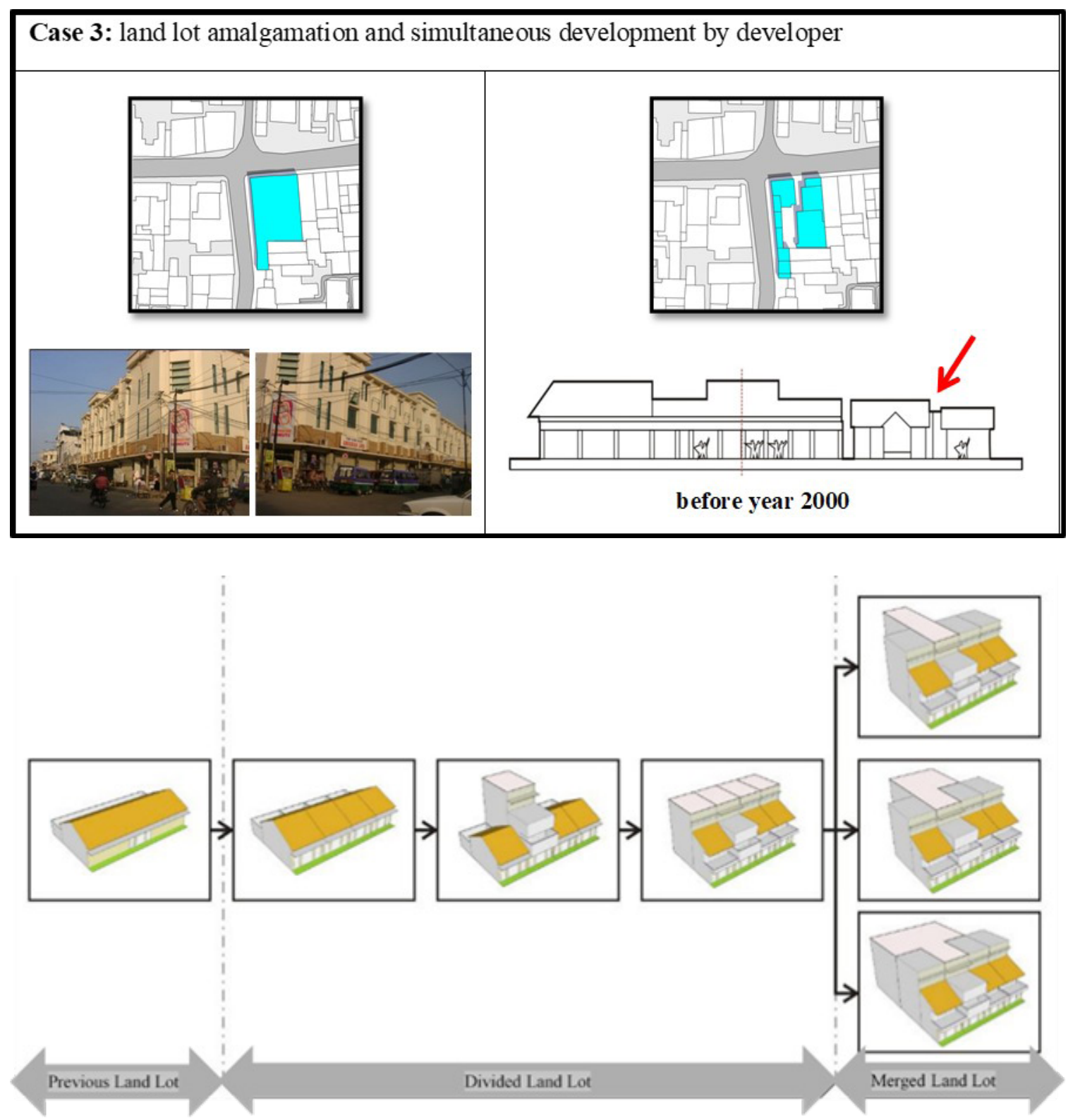

The process of transformation building and site

\section{Conclusion}

The change of land lot ownership is believed to be the driving factor of the site transformation, both fragmentation and amalgamation. Expansion of land mainly occurs toward the inner block which will gradually eliminate residential areas in the city center. Similarly, the dominance of trading activities in shop house building also eliminates the residence space.
Both transformation type, fragmentation and amalgamation create new form of shop house, vertical modern replace the traditional one. Many transformation cases in Pasar Baru area changed the character of Pasar Baru, from the row of low-storey into the row of mediumstorey shop house. This change is supported by the increasing of technology and the economy of the city.

Change is inevitable but it is expected the transformation that has occurred does not eliminate some old shop houses which 
categories as conservation buildings. Similarly, the existence of the building and residential environment should be maintained so that the city center area still livable.

\section{References}

Alexander, Christopher, 1987: A New Theory of Urban Design, Oxford University Press, New York.

Antoniandes, Anthony C. (1990) Poetics of Architecture: Theory of Design, (New York: Van Nostrand Reindhold, Inc)

Habraken, N.J, (1983) Transformation of the Site, (A Water Press, Cambridge, Massachusetts).

Harun, Ismet Belgawan, 2001: Pasar Tanah Perkotaan Informal, Suatu Sketsa Pertanahan di Pinggiran Kota Metropolitan, Info URDI vol 12.

Kunto, Haryoto, 1984 Wajah Bandoeng Tempo Doeloe, (Granesia, Bandung).

Lim, William S.W, 1988: Asian New Urbanism, Select Book, Pte. Ltd, Singapore.

Nas, Peter, J.M, 1986: The Indonesian City, Foris Publication, Dordrecht, Holland/ Cinnaminson, USA.

Nas, Peter, J.M, 2002: The Indonesian Town Revisited, Lit Verlag, Institute of Southeast Asian Studies, Singapore.

Nastiti, Titi Surti, 2003: Pasar di Jawa: Masa Mataram Kuna Abad VIII-IX Masehi, PT. Dunia Pustaka Jaya, Jakarta.

Purwanto, LMF, 2001: Kota Kolonial Lama Semarang (Tinjauan Umum Sejarah Perkembangan Arsitektur Kota, Dimensi Teknik Arsitektur Vol 33 no.1 Juli 2005: 27-33, Universitas Katolik Sugijopranoto, Semarang.

Rahardjo, Supraktikno, 2007: Kota-kota Prakolonial Indonesia: Pertumbuhan dan Keruntuhan, Fakultas Ilmu Pengetahuan Budaya, Universitas Indonesia.

Rapoport, Amos, 1977: Human Aspects of Urban Form, Towards a Man Environment Approach to Urban Form and Design, Pergamon International Library, Great Britain.

Sarosa, Wicaksono, 2001: Sejarah Pertanahan sebagai Latar Belakang Tanah Informal, Info URDI vol.12.
Siregar, Sandi A, 1990 Bandung The Architecture of a City in Development, Urban analysis of a regional capital a contribution to the present debate on Indonesia Urbanity and Architectural Identity Volume I\&II (Doctorate Thesis, Katholieke Universiteit Leuven-Belgia.

Soewarno Nurtati, 2002 Pengaruh Perubahan Bentuk Kavling Rumah-Toko Terhadap Morfologi Bangunan, Studi Kasus: Kawasan Pasar Baru Bandung,( Magister Thesis, Pasca Sarjana, Universitas Katolik Parahyangan Bandung).

Soewarno Nurtati, 2013: Kawasan Pusat Kota sebagai Lingkungan Hunian: Transformasi Arsitektur Hunian di Kawasan Pusat Kota, kasus: Kawasan Pasar Baru-Bandung, (Disertasi, Program Pasca Sarjana, Universitas Katolik Parahyanga Bandung).

Voskuil, RPGA, EA, 1996 Bandoeng, Beeld van een stad, (Asia Major, Purmerend). 